Buca Eğitim Fakültesi Dergisi, 2021, Say1 51, s.384-402

Araştırma Makalesi

\title{
Sivrice Depremini Yaşamış Ortaokul Öğrencilerinin Depreme İlişkin Metaforik Algılarının İncelenmesi: Malatya İli Örneği
}

\section{Examination of Metaphorical Perceptions about Earthquake of Secondary School Students Who Experienced The Sivrice Earthquake: Example of Malatya Province}

\author{
Mustafa DOĞAN ${ }^{1}$, Oğuzhan NACAROĞLU ${ }^{2}$, Selman ABLAK
}

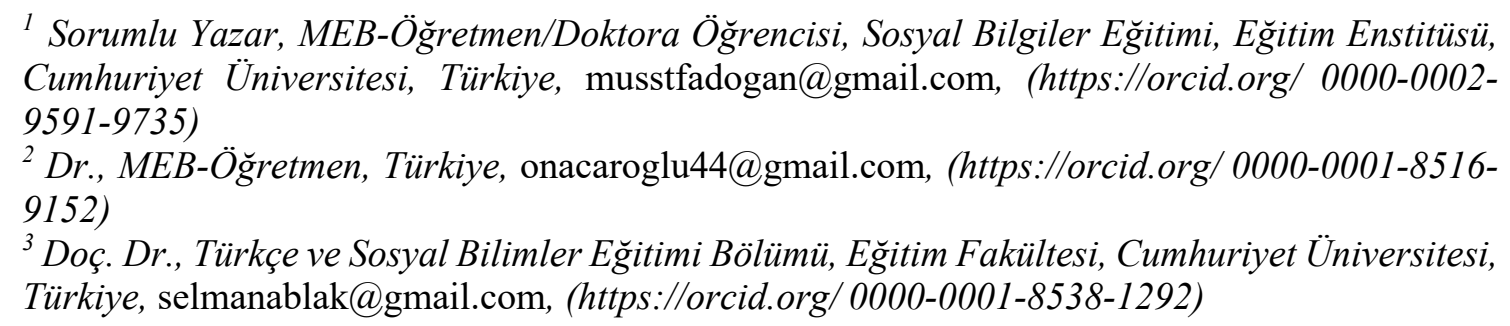

Geliş Tarihi: 22/02/2021

Kabul Tarihi:18/06/2021

\section{öz}

Bu araştırmada, Sivrice depremini yaşamış ortaokul öğrencilerinin depreme ilişkin metaforik algılarının incelenmesi amaçlanmıştır. Araştırmanın çalışma grubunu 151 ortaokul öğrencisi oluşturmaktadır. Araştırmada nitel araştırma yöntemi desenlerinden fenomenoloji deseni kullanılmıştır. Araştırma verileri katılımcıların "Deprem..... gibidir/benzemektedir. Çünkü ...” ifadesine verdikleri cevaplara göre toplanmış ve tümevarımsal içerik analizi yapılarak veriler analiz edilmiştir. Araştırma sonucunda katılımcıların "deprem" kavramına ilişkin 76 adet farklı metafor ürettikleri bulunmuştur. Metaforlar, ortak özellikleri ve kullanım gerekçelerine göre üç kategori ve sekiz alt kategori altında toplanmıştır. Kategoriler; "depremin oluşma şekli", "depremin sonuçları" ve "depremin sebepleri”; alt kategoriler ise makine/araç-gereç, doğal afet, insan davranışı, zaman, psikolojik sonuçlar, toplumsal sonuçlar, dinsel sonuçlar ve dinsel sebepler şeklinde isimlendirilmiştir. Katılımcıların en fazla salıncak ( $f=17)$, kıyamet $(f=15)$, ölüm $(f=12)$, beşik $(\mathrm{f}=9)$, korku $(\mathrm{f}=5)$ ve felaket $(\mathrm{f}=5)$ metaforlarını ürettikleri sonucuna ulaşılmıştır. Elde edilen bu verilerin afet eğitimi çalışmalarının öğrenci düzeyine uygun olacak şekilde planlanmasına, afet eğitimi çalışmalarının etkili bir şekilde yapılabilmesine imkân sağlayacağı düşünülmektedir.

Anahtar Kelimeler: Deprem algısı, fenomenoloji, metafor, ortaokul öğrencileri.

\begin{abstract}
In this research, it was aimed to examine the metaphorical perceptions about earthquake of secondary school students who experienced the Sivrice earthquake. The research group consisted of 151 secondary school students. The phenomenology design, one of the qualitative research method designs, was used in the research. The Research data were collected based on the answers they gave for "Earthquake are like... because..." statements and the data were analyzed by performing an inductive content analysis. As a result of the research, it was found that participants produced 76 different metaphors related to the concept of "earthquake". Metaphors were grouped under three categories and eight subcategories based on their common characteristics and reasons for use. The categories were named" How an earthquake occurs"," the consequences of an earthquake" and "the causes of an earthquake". Subcategories are named as
\end{abstract}


machines/tools-equipment, natural disaster, human behavior, time, psychological consequences, social consequences, religious consequences and religious causes. It was concluded that participants produced the most metaphors of swing ( $\mathrm{f}=17)$, doomsday $(\mathrm{f}=15)$, death $(\mathrm{f}=12)$, cradle $(\mathrm{f}=9)$, fear $(\mathrm{f}=5)$ and disaster $(\mathrm{F}=5)$. It is thought that these data will enable disaster education studies to be planned in accordance with the student level and disaster education studies to be carried out effectively.

Keywords: Earthquake perception, metaphor, phenomenology, secondary school students.

\section{GİRIŞ}

İnsanlar doğal çevreyi etkilemekle birlikte doğal çevrenin etkisinde de kalmaktadır (Hobsbawm, 2013). Buna karşın, doğada meydana gelen deprem, sel, heyelan, volkanik patlama ve firtına gibi olaylar insan hayatını ciddi şekilde etkilemektedir (Zhou, Wu, Xu ve Fujita, 2018). Doğada meydana gelen bu olaylar doğal yaşamın bir parçası olarak gelişen süreçler olup dünyanın oluşumundan itibaren sürekli olarak gerçekleşmektedir. Bu olayların insan yaşamında ortaya çıkardığı yıkıcı etkileri afet olarak tanımlanmaktadır (Şahin ve Sipahioğlu, 2002). Afetler, can ve mal kaybına yol açan, günlük yaşamdaki faaliyetlerin durmasına neden olan ve insanların kendi imkânlarını kullanarak üstesinden gelemediği doğal ve beşeri olaylardır (Ergünay, 1996; Yi, Shao-Hong, Zhong-Chun ve Erfu, 2011). Doğal afetler ise insan yaşamını olumsuz yönde etkileyerek can ve mal kaybına neden olan ve oluşumunda daha çok doğal unsurların etkili olduğu doğa olaylardır (De Haen ve Hemrich, 2007; Şahin ve Sipahioğlu, 2002).

Doğal afetler arasında insan hayatını en fazla etkileyen doğa olayı depremlerdir (Karakuş, 2013; Rij, 2016). Bu durumun nedenleri arasında depremlerin tahmin edilememesi, önlenemez olması ve büyük oranda can ve mal kaybına neden olması gibi nedenleri saymak mümkündür. Depremler, kaynağını yerin derinliklerinden alan ve kısa süreli yer sarsıntıları meydana getiren doğa olaylarıdır (Baytiyeh ve Naja, 2013; İzbırak, 1991). Sahin ve Sipahioğlu (2002) depremi, yer kabuğunda meydana gelen kısa süreli yer sarsıntıları olarak tanımlamaktadır. Depremler oluşum şekilleri bakımından ise tektonik depremler, volkanik depremler, çöküntü depremler olarak sınıflandırılmaktadır (Kasapoğlu, 2007; Obara ve Kato, 2016). Dünyada meydana gelen depremlerin \%98'i tektonik kökenli olup (Karakuş, 2013), oluşum şekilleri bakımından bu depremler en şiddetli etkiyi yaratan depremlerdir (Aksoy ve Sözen, 2014).

Türkiye, dünyan en önemli deprem kuşaklarından birinde yer alan Alp-Himalaya dağ siras1 üzerinde bulunmaktadır. Alp-Himalaya kuşağı dünyadaki depremlerin yaklaşık \%20'sinin görüldüğü aktif bir deprem kuşağıdır (AFAD, 2018). Buna bağlı olarak Anadolu coğrafyası jeolojik olarak fay kırıklarıyla parçalanmış bir yer yapısına sahiptir (Şahin ve Sipahioğlu, 2002). $\mathrm{Bu}$ tektonik özellikleri nedeniyle Türkiye topraklarının büyük bir kısmı deprem tehlikesi altındadır. Genç oluşumlu bir yer yapısına sahip olması nedeniyle Türkiye'de sık aralıklarla depremler yaşanabilmektedir (Özel ve Solmaz, 2012). Dolayısıyla Türkiye'de görülen doğal afetler arasında en çok can ve mal kaybına neden olan doğa olayı depremlerdir (AFAD, 2018; Özkul ve Karaman, 2007). Jeolojik yapıya bağlı olarak Türkiye'de depremlerin görülme şiddeti, bölgeden bölgeye farklılık göstermektedir. Türkiye'de deprem riski, fay hatlarının yoğunluğuna bağlı olarak Kuzey Anadolu, Batı Anadolu ve Doğu Anadolu Fay Hattı üzerinde yer alan yerleşim alanlarında daha çok görülmektedir (Özkul ve Karaman, 2007).

Türkiye'deki aktif fay hatlarından birisi olan Doğu Anadolu Fay Hatt1, Hatay'dan başlayarak Gölbaşı, Hazar gölü, Palu, Bingöl üzerinden geçerek Karlıova civarında Kuzey Anadolu Fay Hattı ile birleşmektedir (Kıvrak, 2019; Pampal, 1999) Tarihsel süreç içerisinde Doğu Anadolu Fay Hattı üzerinde pek çok deprem meydana gelmiştir. 1513 Pazarcık, 1822 Maraş, 1866 Karlıova, 1872 Antakya, 1874 Gezin, 1875 Sivrice, 1893 Malatya-Çelikhan, 1905 Pütürge, 1964 Malatya, 1965 Karlıva, 1966 Varto, 1968 Bingöl-Elazığ, 1971 Bingöl, 1971 Lice, 1977 Palu, 1986 Malatya Sürgü, 1998 Karlıova, 2003 Bingöl depremleri Doğu Anadolu fay hattında meydana gelen başlıca depremlerdir (İmamoğlu ve Çetin, 2007; TMMOB, 2011). Bu 
depremlerden biri de 24 Ocak 2020 tarihinde Elazığ'da meydana gelen ve merkez üssü Sivrice ilçesi olan depremdir (Harita 1).

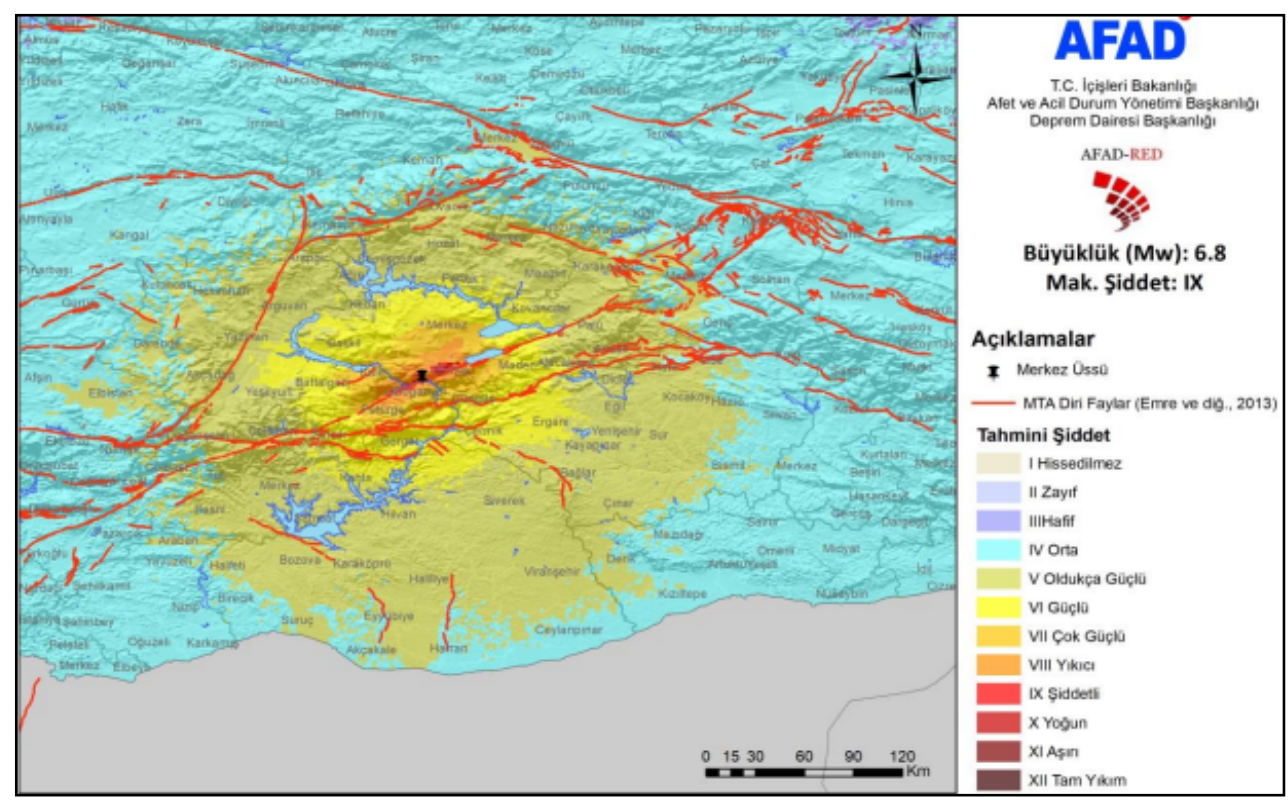

Harita 1. 24 Ocak 2020 Sivrice Depremi Tahmini Şiddet Haritası (AFAD, 2020)

Harita 1 incelendiğinde, Sivrice depreminin geniş bir alanı etkilediği görülmektedir. Kandilli Rasathanesinin verilerine göre depremin büyüklüğü 6.8 olarak gerçekleşmiştir. Doğu Anadolu fay hattında meydana gelen bu deprem başta Sivrice, Elazı ̆̆ kent merkezi, Doğanyol, Pütürge, Malatya kent merkezi ile civar il ve ilçelerde de hissedilmiştir. Depremin neden olduğu can ve mal kayıplarının yanında geniş bir alanda hissedilmiş olması, toplumsal kaygının önemli ölçüde artmasına neden olmuştur. Depremle birlikte bazı okul binalarının zarar görmesi ve devam eden artçı sarsıntılar, öğretim faaliyetlerinin de aksamasına neden olmuştur.

Depremlerin oluşumuna engel olmak mümkün değildir. Buna karşın eğitim faaliyetleriyle depremin vermiş olduğu zararın azaltılması sağlanabilir (Navakanesh, Shah ve Prasanna, 2019; Öcal, 2007). Deprem eğitimi yerkabuğunun yapısını tanıyarak, deprem hakkında bilgi sahibi olmak ve deprem sonrasında ortaya çıkabilecek zararları en aza indirmek için gerekli olan bilgi ve becerilerin kazandırılma sürecidir (Çakar, 2008; Öcal, 2005). Deprem eğitimi çalışmaları, depreme bağlı olarak ortaya çıkan sorunların giderilmesinde bireysel ve toplumsal yeterlilikleri önemli ölçüde artırmaktadır (Çoban, Sözbilir ve Göktaş, 2017). Deprem ve benzeri doğal afetlere ilişkin yürütülen eğitim çalışmalarının formal eğitimin bir parçası olarak sürdürülmesi, afet eğitimi çalışmalarının daha planlı ve programlı olmasını sağlamaktadır (Kırıkkaya, Ünver ve Çakın, 2011). Bu bağlamda okullarda yürütülen afet eğitimi çalışmalarının uygulamalı olarak yürütülmesi önem kazanmaktadır (Kadıoğlu, 2005).

Düzce depremi sonrasında afet konuları, öğretim programlarında daha fazla yer almıştır. İlerleyen süreçte afet eğitimi çalışmalarıyla öğrencilere kazandırılmak istenen afet bilinci, öğretim programlarında yer alan temel kazanımlar arasına girmiştir. Ortaokul düzeyinde afet eğitimi konuları ağırlıklı olarak sosyal bilgiler ve fen bilimleri öğretim programları içerisinde yer almaktadır. 2018 yılında yenilenen sosyal bilgiler öğretim programında afet eğitimiyle ilgili temaların 5. sınıf düzeyinde yoğunlaştığı görülmektedir. 5. sınıf "İnsanlar, Yerler ve Çevreler" öğrenme alanında "Yaşadığ 1 çevredeki afetlerin ve çevre sorunlarının oluşum nedenlerini sorgular." ve "Doğal afetlerin toplum hayatı üzerine etkilerini örneklerle açıklar." kazanımları yer almaktadır. 7. sınıf Küresel Bağlantılar öğrenme alanında ise afet eğitimi konuları küresel sorunlar arasında ele alınmıştır (MEB, 2018a). Fen bilimleri öğretim programında yer alan afet konularının ise 5. sınıf düzeyinde daha çok yoğunlaştığı görülmektedir. "İnsan ve Çevre / Canlılar 
ve Yaşam" öğrenme alanında yer alan afet eğitimi konuları "Yıkıcı Doğa Olayları" başlığı altında incelenmiştir. Konuya ilişkin kazanımlar: "Doğal süreçlerin neden olduğu yıkıcı doğa olaylarını açıklar.", "Depremler, volkanik patlamalar, seller, heyelanlar, hortum, kasırgalara ayrıntıya girilmeden değinilir.", "Yıkıcı doğa olaylarından korunma yollarını ifade eder" şeklinde ifade edilmiş̧tir (MEB, 2018b).

Afet eğitimi çalışmaları kapsamında depremler, pek çok çalışmanın konusu olarak ele alınmaktadır. Bu durumu depremlerin Türkiye'deki etkisiyle açıklamak mümkündür. Özellikle 1992 Erzincan depremi ve 1999 Gölcük ve Düzce depremlerin sonrasında, depremlere ilişkin araştırmaların arttığı görülmektedir (Aksoy ve Sözen, 2014; Altay, 2008; Çakar, 2008; Çelik, Dur ve Bayar 2016; Çoban, Sözbilir ve Göktaş 2017; Değirmençağ ve Cin, 2016; Doğan ve Koç, 2017; Karakuş, 2013; Öcal, 2007; Öztürk, 2013; Sözen, 2019; Yükseller, 2019). Benzer durum Türkiye dışında yapılan çalışmalarda da göze çarpmaktadır (Izadkhah ve Gibbs, 2015; Johnson ve Ronan, 2014; Navakanesh, Shah ve Prasanna, 2019; Mutch, 2015; Tsai, 2001). Depremler insan hayatını derinden etkileyen doğal afetler olmaları nedeniyle, hem meydana geldiği zaman diliminde, hem de daha sonra insan bilincini derinden etkilemektedir (Karakuş, 2013). Bu nedenle depremi yaşamış olan öğrencilerin, depreme ilişkin bilgi düzeylerinin, algılarının ve görüşlerinin incelenmesi önem kazanmaktadır (Aydın, 2019; Cvetković vd., 2015; Kung ve Chen, 2012; Rahman, 2019).

Alanyazın tarandığında; öğretmen adaylarının depremlere ilişkin bilgi düzeylerinin (Öcal, 2005), depremi yaşamış ve yaşamamış öğrencilerin depreme ilişkin algı düzeylerinin (Karakuş, 2013), lise öğrencilerinin deprem eğitimine ilişkin görüşlerinin (Aksoy ve Sözen, 2014) incelendiği çalışmalar yer almaktadır. Aynı şekilde Aksoy (2013) tarafindan 9. sınıf öğrencilerinin deprem kavramını algılama biçimleri, Çelik ve diğerleri (2016) tarfindan okul öncesi çocuklarının deprem algıları, Öztürk (2013) tarfından ise sınıf öğretmeni adaylarının deprem deneyimleri üzerine araştırma yapılmıştır. Tanhan ve Mukba (2015) tarafından yapılan çalışmada ise öğrencilerin depreme ilişkin algıları ve depremin öğrenciler üzerindeki etkisi incelenmiştir. Buna karşın depremi yaşamış ortaokul öğrencilerinin depreme ilişkin algılarının belirlenmesine ilişkin herhangi bir çalışmaya rastlanılmamıştır. Özellikle küçük yaştaki çocukların depreme ilişkin algılarını kültür, yaş, sınıf seviyesi gibi değişkenler etkileyebilmektedir (Rahman, 2019). Dolayısıyla ortaokul öğrencilerinin depreme ilişkin algılarının incelenmesi önem arz etmektedir. Türkiye'de depremi yaşamış ortaokul öğrencilerinin deprem algılarını inceleyen yeterli sayıda çalışmanın olmaması nedeniyle mevcut çalışmanın alanyazına katkı sağlayacağı düşünülmektedir. Öğrencilerin bir olgu, kavram veya olay hakkında algılarını belirlemek için farklı teknik, yol ve ölçme araçları kullanılmaktadır. Bu yollardan biri olarak da öğrencilerin sahip oldukları metaforlar gösterilmektedir (Potts ve Semino, 2019; Özdemir ve Akkaya, 2013).

Metafor, Yunanca meta ve pherein kelimelerinin birleşimi olan "metapherein"den gelmektedir (Şahan, 2017). Metaforlar, kavramların oluşumuna yönelik bireylerin düşüncelerini yapılandıran ve kontrol eden güçlü zihinsel araçlardan biridir (Hogler, Gross, Hartman ve Cunliffe, 2008; Shaw ve Mahlios, 2011). Bu kapsamda Potts ve Semino (2019) metaforların hem iletişim hem de düşünme aracı olduklarını belirtmiş̧lerdir. Collins English Dictionary'de metaphor "Bir kavramı, durumu veya düşünceyi gerçek bir benzerlik kurmadan farklı bir şekilde ifade etmenin yaratıcı yolu" olarak tanımlanmaktadır (Collins English Dictionary, 2020). Bir başka İngilizce sözlükte "Bir şeyi aynı niteliklere sahip başka bir şeyle karşılaştırarak tanımlamanın bir yolu." olarak tanımlanmaktadır (Cambridge Dictioanary, 2020). TDK sözlüğünde ise metafor "Kelimeyi veya kavramı kabul edilenin dışında başka anlamlara gelecek biçimde kullanma" olarak tanımlanmıştır (TDK, 2020). Metaforlar ile bireyler, kavramlar ile nesneleri bağdaştırmaktadır (Arslan ve Bayrakçı, 2006). Başka bir ifadeyle metaforlar, bireylerin anlatırken zorlandıkları düşüncelerini ifade etmelerine firsat veren zihinsel tasarımlardır (Shaw ve Mahlios, 2011). Dolayısıyla mevcut çalışmada ortaokul öğrencilerinin depreme ilişkin algıları, metaforlar yardımıyla belirlenmeye çalışılmıştır. Alanyazında öğrencilerin belli kavramlara 
yönelik algılarını ortaya koymak için metaforların sıklıkla tercih edildiği görülmektedir. Örneğin farklı yaş ve gelişim düzeyine sahip öğrencilerin; bilim (Thibodeau, Flusberg ve Holmes, 2017), mikroskop (Ekici, 2016), kanser (Potts ve Semino, 2019), çevre (Doğan, 2017), evrensel değerler (Çelikkaya ve Seyhan, 2017), oyun (Tok, 2018), algoritma (Gökoğlu, 2017) gibi kavramlara yönelik algılarını belirlemek için metaforlar kullanılmıştır. Mevcut çalışmada da ortaokul öğrencilerinin depreme ilişkin algıları metaforlar yardımıyla incelenmiştir. Sonuç olarak ortaokul öğrencilerinin depreme ilişkin metaforik algılarının araştırılması, deprem eğitimiyle ilgili süreçlerin doğru planlanmasına katkı sağlayabilir. Afet eğitimi çalışmalarının en önemli alt başlıklarından birisi olan deprem eğitimi çalışmalarının, öğrencilerin algılama düzeylerine uygun olarak gerçekleştirilmesi, söz konusu eğitim faaliyetlerinin verimliliğini artırabilir. Bu bağlamda elde edilecek verilerin okullarda yürütülmekte olan deprem eğitimi çalışmalarının, öğrencilerin algılama şekillerine uygun olarak düzenlenmesi ve bu sayede söz konusu eğitim faaliyetlerinin daha verimli hâle getirilmesi beklenmektedir. $\mathrm{Bu}$ doğrultuda aşağıda verilen alt problemlere cevap aranmıştır.

1. Sivrice depremini yaşamış ortaokul öğrencilerinin, "depreme" ilişkin metaforlanı nelerdir?

2. Sivrice depremini yaşamış ortaokul öğrencilerinin "deprem" kavramıyla ilgili metaforları ortak özellikler bakımından hangi kavramsal kategoriler altında ifade edilebilir?

\section{YÖNTEM}

\subsection{Araștırma Modeli}

Sivrice depremini yaşamış ortaokul öğrencilerinin depreme yönelik metaforik algılarının incelenmesinde nitel araştırma yönteminden fenomenoloji deseni kullanılmıştır. Fenomenoloji, derinlemesine bilgi sahibi olunmayan olguları araştırmayı hedefleyen bir desendir (Büyüköztürk, Çakmak, Akgün, Karadeniz ve Demirel, 2016; Creswell, 2007). Bu desende olgular, bu olguyu en iyi yansıtacak kişi ya da grupların bakış açıları çerçevesinde yorumlanmaya çalışılır (Patton, 2002).

\section{2. Çalışma Grubu}

Araştırmanın çalışma grubunu 151 ortaokul öğrencisi oluşturmaktadır. Araştırmanın katılımcıları amaçlı örnekleme yönteminden maksimum çeşitlilik örnekleme yöntemine göre seçilmiştir. Maksimum çeşitlilik örnekleme yönteminde araştırmanın amacı doğrultusunda kendi içinde benzeşik farklı durum veya kişiler üzerinde çalışmanın yapılması temeline dayanır (Büyüköztürk vd., 2016). Bu kapsamda cinsiyet ve sınıf seviyesi açısından çeşitlilik gösteren gönüllü ortaokul öğrencileri çalışmaya dâhil edilmiştir. Araştırmaya katılan 176 katılımcıdan 25'inin yanıtları, formdaki ifadelerin boş bırakılması, eksik bırakılması veya metafor ile metaforun açıklandığı cümle arasında anlam bütünlüğünün olmaması sebebiyle değerlendirmeye alınmamıştır. Örneğin "Deprem..... gibidir/benzemektedir. Çünkü deprem korkunçtur." cevap formu metafor kısmı boş bırakıldığından değerlendirme dışı bırakılmıştır. Araştırmaya dâhil edilen 151 katılımcının demografik özellikleri Tablo 1'de özetlenmiştir.

Tablo 1. Katılımcılara Yönelik Demografik Bilgiler

\begin{tabular}{llcc}
\hline Değişkenler & Demografik özellikler & $f$ & $\%$ \\
\hline \multirow{2}{*}{ Cinsiyet } & Kiz & 80 & 52,98 \\
& Erkek & 71 & 47,01 \\
\hline \multirow{3}{*}{ Sinıf Seviyesi } & 5. Sinıf & 32 & 21,19 \\
& 6. Sinıf & 35 & 23,18 \\
& 7. Sinıf & 35 & 23,18 \\
& 8. Sinıf & 49 & 32,45 \\
\hline
\end{tabular}

Tablo 1 incelendiğinde, katılımcıların \%52,98'ini kı, \%47.01'ini ise erkek ortaokul öğrencileri oluşturmaktadır. Sınıf seviyelerine ilişkin bilgilere bakıldığında katılımcıların 
\%21,19'u beşinci, \%23,18'i altınc1, \%23,18'i yedinci, \%32,45'i ise sekizinci sınıfta öğrenimlerine devam etmektedir.

\subsection{Verilerin Toplanması}

Araştırmada ortaokul öğrencilerinin depreme yönelik metaforları iki bölümden oluşan açık uçlu anket formu kullanılarak toplanmıştır. Birinci bölümde katılımcıların cinsiyet, sınıf seviyesi durumunu betimleyen sorular; ikinci bölümde ise katılımcıların depreme ilişkin sahip oldukları metaforları ortaya çıkarmak amacıyla verilen "Deprem .........gibidir/benzemektedir. Çünkü,

.." kalıp cümlesi yer almıştır. Bu kalıp cümlesindeki "gibi" ifadesiyle metafor ile kaynağ arasındaki ilişkinin ortaya konması, "çünkü" ifadesiyle benzetmenin gerekçesinin açılanması hedeflenmektedir (Tok, 2018). Uygulamaya geçmeden önce öğrencilerle "okul” kavramı ile örnek bir çalışma yapılmış olup daha sonra asıl uygulamaya geçilerek katılımcıların formu doldurmaları sağlanmıştır.

\subsection{Verilerin Analizi}

$\mathrm{Bu}$ araştırmada verilerin analizinde tümevarımsal içerik analizi kullanılmıştır. İçerik analizinde toplanan veriler düzenlenerek kategoriler hâlinde sunulur (Yıldırım ve Şimşek, 2011). Alanyazın tarandığında metafor çalışmalarında içerik analizinin; eleme/numaralandırma, kodlama, kategorilerin oluşturulması, geçerlik ve güvenirlik çalışmaları ve verilerin yorumlanması aşamaları dikkate alınarak yapıldığı görülmektedir (Ateş ve Karatepe, 2013; Büyükalan-Filiz ve Türkmenli, 2019; Saban, Koçbeker ve Saban, 2006; Tok, 2018). Bu araştırmada da verilerin analizinde benzer aşamalar takip edilmiştir.

Verilerin elenmesi ve numaralandırılması: Bu aşamada öncelikle verilen cevapların araştırma amacına uygun olup olmadığ incelenmiştir. Araştırmaya katılan 176 katılımcının 25'inin cevap kâğıtlarının araştırmanın amacına uygun olmadığına karar verilmiştir. $\mathrm{Bu}$ kapsamda bu katılımcıların cevap kâğıtları değerlendirmeye alınmamıştır. Geriye kalan 151 cevap kağıdına K1, K2, K3, .., K151 şeklinde numaralar verilmiştir.

Verilerin kodlanması: $\mathrm{Bu}$ aşamada, değerlendirmeye alınmasına karar verilen cevap kâğıtlarına ait metaforlar birden başlanarak numaralandırılmıştır. Bu işlemin sonucunda 76 adet farklı kod tespit edilmiştir. Araştırmacıların belirledikleri kodlar ile metaforlar listelenerek her bir metafora ait frekans değerleri yazılmıştır.

Kategorilerin oluşturulması: Katılımcıların cevapları ortak özellikleri bakımından incelenmiştir. $\mathrm{Bu}$ kapsamda cevaplar katılımcıların deprem kavramına bakış açılarına göre değerlendirilmiş ve üç kategori ile sekiz alt kategori oluşturulmuştur.

Geçerlik ve güvenirlik sağlanması: Bu araştırmada geçerliği ve güvenirliği sağlamak için inandırıcılık, aktarılabilirlik, tutarlık ve teyit edilebilirlik stratejileri kullanılmıştır (Shenton, 2004). İç geçerlikle ilgili olan inandırıcılık için geliştirilen form uzman görüşüne sunulmuştur. Uzman görüşü neticesinde "deprem" kavramının metafor formunda kullanılmasına karar verilmiştir. Ayrıca inandırıcılığı arttırmak için bulgular kısmında öğrencilerin cevapları doğrudan aktarılmıştır. Araştırmanın dış geçerliği ile ilgili olan aktarılabilirlik kapsamında çalışmada amaçlı örnekleme yöntemi kullanılmıştır (Lincoln ve Guba, 2013). Bunun yanı sıra veri toplama ve analiz süreci detaylı bir şekilde açıklanmıştır. Araştırmanın tekrar edilebilirliği ve güvenirliği ile ilgili olan tutarlılık (Lincoln ve Guba, 2013) kapsamında elde edilen veriler iki araştırmacı tarafından ayrı ayrı daha sonra ise birlikte analiz edilmiştir. Bu çalışmaların sonucunda ortak kategori ve kodlar belirlenmiştir. Ayrıca verilerin değerlendirilmesi için kelime bulutu da hazırlanmıştır.

Verilerin yorumlanması: Veri analizinde ortaokul öğrencilerinin deprem ile ilgili metaforları kategorileştirilmiş olup gerekçeli ifadeleri de belirtilmiştir. $\mathrm{Bu}$ metaforlar ve kategorileri şekil ve tablolar hâlinde sunularak yorumlanmıştır. 


\subsection{Araştırmanın Etik İzinleri}

Etik değerlendirmeyi yapan kurul ad $1=$ Sivas Cumhuriyet Üniversitesi Bilimsel Araştırma ve Yayın Etiğgi Sosyal ve Beşeri Bilimler Kurulu

Etik değerlendirme kararının tarihi= 27.07.2020

Etik değerlendirme belgesi sayı numarası= 60263016-050.06.04-E.469586

\section{BULGULAR}

\subsection{Ortaokul Öğrencilerinin "Deprem” Kavramına İlişskin Metaforları}

Araştırmaya katılan ortaokul öğrencilerinin “deprem” kavramına ilişkin 76'sı farklı olmak üzere toplamda 151 metafor ürettikleri bulunmuştur. Üretilen metaforlar ve metaforlara ilişkin frekans değerleri Tablo 2'de gösterilmiştir.

Tablo 2. Katılımcıların Deprem Kavramına Yönelik Ürettikleri Metaforlar

\begin{tabular}{|c|c|c|c|}
\hline Metafor & $f$ & Metafor & $f$ \\
\hline Salıncak & 17 & Korku makinesi & 1 \\
\hline Kiyamet & 15 & Bomba & 1 \\
\hline Ölüm & 12 & Taşların vurması & 1 \\
\hline Beşik & 9 & $\mathrm{C}_{1} \mathrm{~g}$ & 1 \\
\hline Korku & 5 & Sel & 1 \\
\hline Felaket & 5 & Habersiz canavar & 1 \\
\hline Kiyamet alameti & 4 & Yer yarığı & 1 \\
\hline Ceza & 3 & Kitap & 1 \\
\hline Rüya & 3 & Darbe & 1 \\
\hline Yilan & 3 & Arkadaşın itmesi & 1 \\
\hline Gemi & 2 & Yangin & 1 \\
\hline Film & 2 & Çaresizlik & 1 \\
\hline Sinav & 2 & Fil & 1 \\
\hline Kızgınlık & 2 & Meteorun yere düşmesi & 1 \\
\hline Mahşer & 2 & Aracın çukura girmesi & 1 \\
\hline Düşman & 2 & Rüzgâr & 1 \\
\hline Savaş & 2 & Uçak & 1 \\
\hline Korku filmi & 2 & Kayaların savaşı & 1 \\
\hline Yatak & 2 & Vahşi bir hayvan & 1 \\
\hline Basketbol topu & 1 & Bebek & 1 \\
\hline Can alıc1 & 1 & Enkaz & 1 \\
\hline Kanepe & 1 & Ruhsal bozukluk & 1 \\
\hline Sira & 1 & Uyandırma cezası & 1 \\
\hline Gondol & 1 & Ezan & 1 \\
\hline Felaket habercisi & 1 & Ağaçta sallanan elma & 1 \\
\hline Traktör & 1 & Haciyatmaz & 1 \\
\hline Acilı anne & 1 & Vişne & 1 \\
\hline Kolon & 1 & Cansız varlık & 1 \\
\hline Muz & 1 & Sinir patlamas1 & 1 \\
\hline Su dalgası & 1 & Aşk & 1 \\
\hline Kiyamet provası & 1 & Kötü his & 1 \\
\hline Habersiz misafir & 1 & Sevdiklerini kaybetmek & 1 \\
\hline Saman alevi & 1 & Tahterevalli & 1 \\
\hline Deniz dalgası & 1 & Kâbus & 1 \\
\hline Yıkılmış hayal & 1 & Yay & 1 \\
\hline El yıkamak & 1 & Ölüm makinesi & 1 \\
\hline Çalışma masası & 1 & Ölüm zamanı & 1 \\
\hline Karanlık & 1 & Silah & 1 \\
\hline
\end{tabular}


Tablo 2'de görüldüğü üzere katılımcıların depreme ilişkin ürettikleri metaforlar kullanım sıklıklarına göre verilmiștir. Bu metaforlardan katılımcıların en fazla kullandıkları metaforların salıncak ( $\mathrm{f}=17)$, kıyamet $(\mathrm{f}=15)$, ölüm $(\mathrm{f}=12)$, beşik $(\mathrm{f}=9)$, korku $(\mathrm{f}=5)$, felaket $(\mathrm{f}=5)$, kıyamet alameti $(\mathrm{f}=4)$, ceza $(\mathrm{f}=3)$, rüya $(\mathrm{f}=3)$ ve yılan $(\mathrm{f}=3$ ) olduğu bulunmuştur. Ayrica dokuz metaforun ikişer, 57 metaforun ise birer kez kullanıldığı belirlenmiştir. Ortaokul öğrencilerinin depreme ilişkin geliştirdikleri metaforların kelime bulutu Şekil 2'de sunulmuştur.

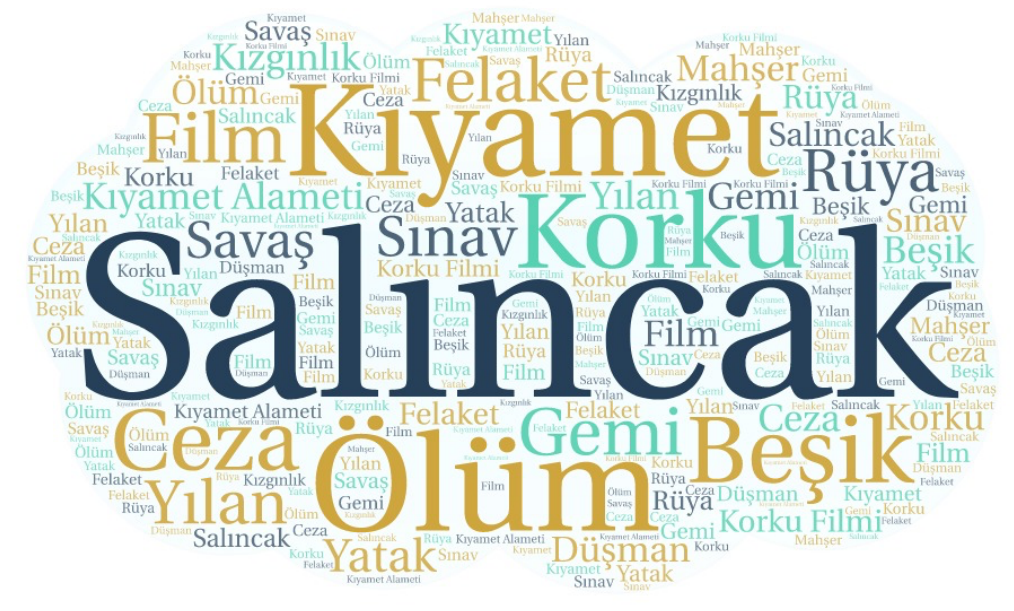

Şekil 2. Deprem Metaforlarına İlişkin Kelime Bulutu

Şekil 2'de görüldüğü üzere katılımcılar en fazla salıncak, kıyamet, ölüm, beşik, korku ve felaket gibi metaforlar üretmişlerdir.

\subsection{Deprem Kavramına İlişsin Metaforların Kategorilendirilmesi}

Ortaokul öğrencilerinin depreme ilişkin ürettikleri 76 metafor ortak özellikleri ve kullanım gerekçeleri açısından üç kategori ve sekiz alt kategori altında toplanmıştır. Kategoriler ve alt kategoriler Şekil 3 ’te verilmiştir.

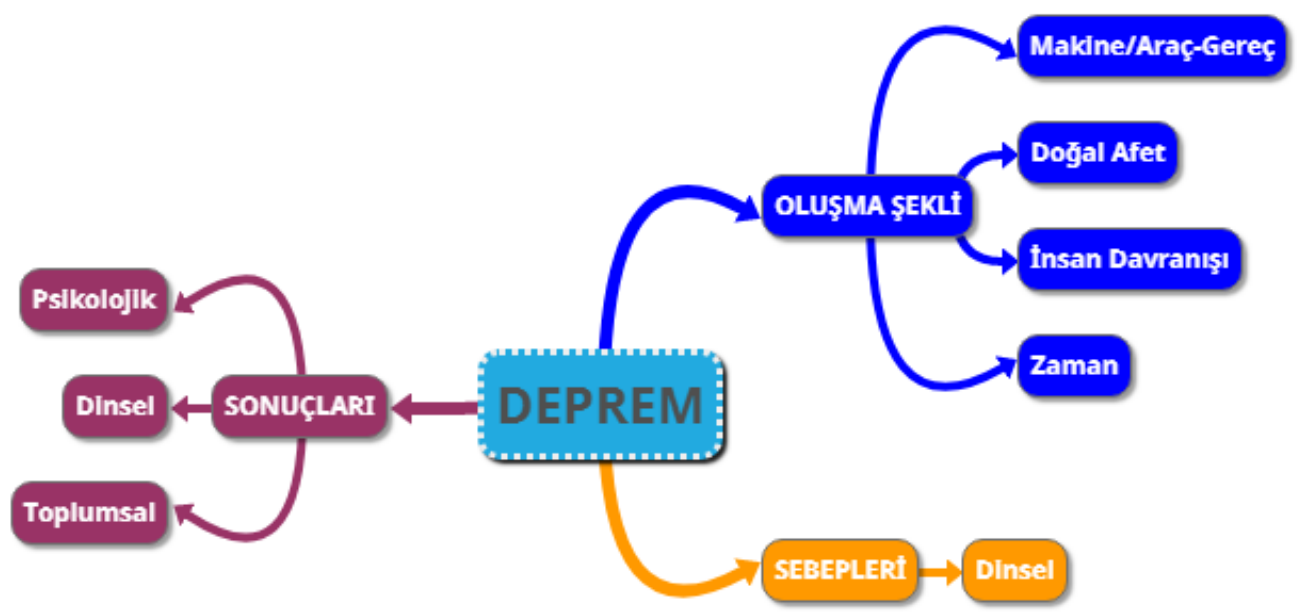

Şekil 3. Deprem Metaforlarına Ait Kategoriler ve Alt Kategoriler

Şekil 3'e bakıldığında, ortaokul öğrencilerinin depreme ilişkin ürettikleri metaforların "Depremin Oluşma Şekli", "Depremin Sonuçları" ve "Depremin Sebepleri" şeklinde üç kategorinin altında toplandığ görülmektedir. Birinci kategori makine/araç-gereç, doğal afet, insan davranışı ve zaman; ikinci kategori psikolojik sonuçlar, toplumsal sonuçlar ve dinsel sonuçlar; üçüncü kategorisi ise dinsel sebepler alt kategorisinden oluşmaktadır. Bu kategorilerde yer alan metaforlar ve açıklama örnekleri tablolar hâlinde sırasıyla sunulmuştur. Ortaokul 
öğrencilerinin "Depremin Oluşma Şekli" kategorisinden makine/araç-gereç alt kategorisine ait metaforlar ve açıklama örnekleri Tablo 3'te verilmiştir.

Tablo 3. Makine/Araç-Gereç Alt Kategorisine Ait Kodlar ve Açıklama Örnekleri

\begin{tabular}{|c|c|c|}
\hline Alt Kategori & Metafor & Açıklama örnekleri \\
\hline 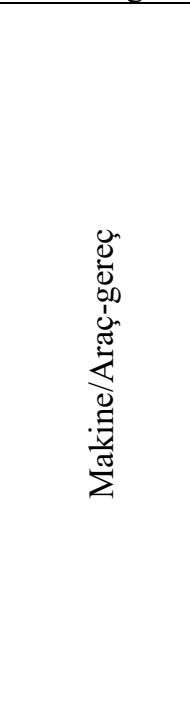 & $\begin{array}{l}\text { Salıncak } \\
\text { Beşik } \\
\text { Gemi } \\
\text { Yatak } \\
\text { Kanepe } \\
\text { Sira } \\
\text { Gondol } \\
\text { Traktör } \\
\text { Çalışma masası } \\
\text { Korku makinesi } \\
\text { Bomba } \\
\text { Uçak } \\
\text { Haciyatmaz } \\
\text { Tahterevalli } \\
\text { Yay } \\
\text { Ölüm makinesi } \\
\text { Aracın çukura girmesi } \\
\text { Basketbol topu }\end{array}$ & $\begin{array}{l}\text { Bir ileri bir geri gidip geliyoruz (K113) } \\
\text { Bir sağa bir sola gidip gelir (K50) } \\
\text { Her dalgada sallanır (K82) } \\
\text { Yatakta her dönüşümde depremi hissederim (K140) } \\
\text { Oturduğunda içindeki yaylar sallanır (K23) } \\
\text { Sallanması deprem hissi uyandırır (K24) } \\
\text { Çok fazla sallanır (K59) } \\
\text { Çalışırken titrer, giderken sallanır (K71) } \\
\text { En olmadık yerde sallanır (K98) } \\
\text { Aniden olup insanları korkutur (K89) } \\
\text { Sarsıntılar yaşarız. Bittiğinde evler y1kılır (K85) } \\
\text { Sarsıntılı ve gürültülü (K25) } \\
\text { Bir sağa bir sola hareket edersin (K30) } \\
\text { Çok sallanır (K122) } \\
\text { Olunca insanı da yay gibi sallar (K95) } \\
\text { Olduğu zaman hayallerinle beraber her şeyin yıkılır (K34) } \\
\text { Çok hızlı, sarsıcı (K3) } \\
\text { Olduğunda her zaman sallanıyor (K21) }\end{array}$ \\
\hline
\end{tabular}

Tablo 3'te görüldüğü üzere "Makine/Araç-gereç" alt kategorisi altında 18 metafor bulunmaktadır. Katılımcıların açıklamaları incelendiğinde, depremi bir makine ya da araca benzeterek bu makine ya da aracın özelliklerine göre depremin oluşma şeklini açıkladıkları görülmektedir. Katılımcıların "Depremin Oluşma Şekli" kategorisinden "Doğal Afet" alt kategorisine ait metaforlar ve açıklama örnekleri Tablo 4'te verilmiştir.

Tablo 4. Doğal Afet Alt Kategorisine Ait Kodlar ve Açıklama Örnekleri

\begin{tabular}{lll}
\hline Alt Kategori & Metafor & Açıklama örnekleri \\
\hline & Su dalgası & Dalgalı ve enerjisini boşalttı̆̆ında sarsıntı olur (K36) \\
& Deniz dalgası & O kadar sallandık ki denizdeymişim gibi hissettim (K76) \\
& Çı̆̆ & Karlar üzerine düştüğünde yer de sarsılır (K80) \\
& Sel & Önüne aldı̆̆ı her şeyi götürür (K84) \\
& Yer yarı̆̆1 & Olduğundan nerde başladıysa orada evler yıkılır (K38) \\
& Meteorun yere düşmesi & Çok şiddetli ve korkutucu (K2) \\
& Rüzgâr & İnsanları, evleri sarsıyor (K22) \\
Kayaların savaşı & Kayalar birbirine çarparak yeryüzünü sallar (K8) \\
& Yangın & Hemen parlar ve insanlar aceleyle dışarı çıar (K139) \\
& Taşların vurması & Deprem olurken sanki eve büyük taşlar vuruyormuş gibi \\
& hissettim (K87) \\
\hline
\end{tabular}

Tablo 4'te görüldüğü üzere "Doğal Afet" alt kategorisi altında 10 metafor bulunmaktadır. Katılımcıların açıklamaları incelendiğinde, depremin oluşma şeklini doğal bir afete benzettikleri görülmektedir. Katılımcıların "Depremin Oluşma Şekli" kategorisinden insan davranışı alt kategorisine ait metaforlar ve açıklama örnekleri Tablo 5'te verilmiştir.

Tablo 5. İnsan Davranışı Alt Kategorisine Ait Kodlar ve Açıklama Örnekleri

\begin{tabular}{lll}
\hline Alt Kategori & Metafor & Açıklama örnekleri \\
\hline & Kızgınlık & Bir anda her şey kızgın bir insan gibi sallanır (K148) \\
İnsan & Arkadaşın itmesi & Öyle bir sarsılırsınız ki sanki öleceksin gibi olursun (K108) \\
davranışı & Düşman & $\begin{array}{l}\text { Düşmanınız ne kadar büyük olursa size zararı o kadar fazla olur } \\
\text { (K68) }\end{array}$ \\
& Bebek & Bebek de ağlarken sallanır (K42) \\
\hline
\end{tabular}


Tablo 5'te görüldüğ̈̈ üzere "İnsan Davranışı" alt kategorisi altında dört metafor bulunmaktadır. Katılımcıların açıklamaları incelendiğinde, depremin oluşma şeklini insan davranışına benzettikleri görülmektedir. Katılımcıların "Depremin Oluşma Şekli” kategorisinden "Zaman" alt kategorisine ait metaforlar ve açıklama örnekleri Tablo 6'da verilmiştir.

Tablo 6. Zaman Alt Kategorisine Ait Kodlar ve Açıklama Örnekleri

\begin{tabular}{|c|c|c|}
\hline Alt Kategori & Metafor & Açıklama örnekleri \\
\hline \multirow{4}{*}{$\begin{array}{l}\text { ज్ } \\
\text { స్త్ } \\
\text { N }\end{array}$} & Habersiz misafir & $\begin{array}{l}\text { Ne zaman geleceğini ne zaman gideceğini hiçbirimiz bilemeyiz } \\
\text { (K141) }\end{array}$ \\
\hline & Saman alevi & Yaşandığ 1 anda hemen olup biter (K123) \\
\hline & Habersiz canavar & Ummadığımız bir zamanda gelir, her şeyi parçalar (K33) \\
\hline & Can alici & Zamanı belli olmaz, bir anda ortaya çıkar (K4) \\
\hline
\end{tabular}

Tablo 6'da görüldüğ̈̈ üzere "Zaman” alt kategorisi altında dört metafor bulunmaktadır. Katılımcıların açıklamaları incelendiğinde, depremi zaman açısından açıkladıkları görülmektedir. Ortaokul öğrencilerinin "Depremin Sonuçları" kategorisinden "Psikolojik Sonuçlar" alt kategorisine ait metaforlar ve açıklama örnekleri Tablo 7'de verilmiştir.

Tablo 7. Psikolojik Sonuçlar Alt Kategorisine Ait Kodlar ve Açılama Örnekleri

\begin{tabular}{|c|c|c|}
\hline Alt Kategori & Metafor & Açıklama örnekleri \\
\hline \multirow{22}{*}{ 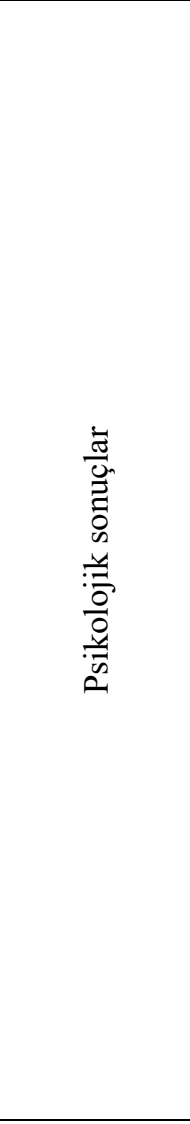 } & Korku filmi & Filmden farksız hayaller ve evler yıkılır (K44) \\
\hline & Acılı anne & Onun feryadı depremin kendisidir (K93) \\
\hline & Muz & Üstüne basarsan düşersin ve psikolojin bozulur (K14) \\
\hline & Vişne & Eksi ve kırmızı (K16) \\
\hline & Yıkılmış hayal & Her yer yıkılıyor benimse hayallerim (K81) \\
\hline & Çaresizlik & $\begin{array}{l}\text { Duygulara dökülemeyecek kadar korkunç ve hüzün verici } \\
\text { (K17) }\end{array}$ \\
\hline & Ruhsal bozukluk & $\begin{array}{l}\text { Maddi ve manevi her şeyini kaybedersin. Bunalım } \\
\text { vazgeçilmez olur (K46) }\end{array}$ \\
\hline & Sinir patlamas1 & $\begin{array}{l}\text { Ne zaman geleceği belli değil gelince de bunalım geçiririz } \\
\text { (K112) }\end{array}$ \\
\hline & Kötü his & Herkes korkar ve bu korku ömür boyu devam eder (K145) \\
\hline & Kâbus & $\begin{array}{l}\text { Korkutucudur, sanki yürüyorsun yolunu bulamıyorsun } \\
\text { (K142) }\end{array}$ \\
\hline & Yilan & Sessiz bir şekilde gelir ve korku verir (K19) \\
\hline & Sevdiklerini & Deprem anında oluşabilecek tek korku sevdiklerini \\
\hline & kaybetmek & kaybetmektir (K151) \\
\hline & Aşk & Kalbinde bir enkaz birakır (K124) \\
\hline & Kolon & $\begin{array}{l}\text { Yik1lir ve maalesef evle beraber hayallerimiz de yok olur } \\
\text { (K75) }\end{array}$ \\
\hline & El yıkamak & Takıntı oluşturur, tekrar tekrar her şey yeniden başlar (K97) \\
\hline & Film & $\begin{array}{l}\text { Yaşam mucizelerini, can kayıplarını, üzüntüleri ifade eder } \\
\text { (K116) }\end{array}$ \\
\hline & Karanlık & Herkes korkar ve endişelenir (K134) \\
\hline & Kitap & Deprem olunca hayatın yıkılır ve roman olur (K41) \\
\hline & Rüya & Olunca rüyada olduğunu hisseder ve şok olursun (K61) \\
\hline & Vahşi bir hayvan & Kaçsan da o korkudan kurtulamıyorum (K54) \\
\hline & Korku & Ölüm ensende ve bekliyor seni (K43) \\
\hline
\end{tabular}

Tablo 7'de görüldüğü üzere "Psikolojik sonuçlar" alt kategorisi altında 21 metafor bulunmaktadır. Metaforlara ilişkin açıklamalar incelendiğinde katılımcıların depremi genel olarak ruhsal bozulmalarla açıkladıkları görülmektedir. Katılımcıların "Depremin Sonuçları" kategorisinden "Toplumsal Sonuçlar" alt kategorisine ait metaforlar ve açıklama örnekleri Tablo 8 'de verilmiştir. 
Tablo 8. Toplumsal Sonuçlar Alt Kategorisine Ait Kodlar ve Açıklama Örnekleri

\begin{tabular}{cll}
\hline Alt Kategori & Metafor & Açıklama örnekleri \\
\hline & Felaket & Evler, binalar yıkılır. İnsanlar perişan olur (K48) \\
& Cansız varlık & Binlerce insan ölür ve cansız varlı olur (K20) \\
& Darbe & Insanlar birlik olup zarar gören insanlara yardım ediyorlar \\
Toplumsal & Ağaçta sallanan elma & (K132) \\
Sonuçlar & Silah & Manları ke can kaybırır sallar ve düşürür (K74) \\
& Savaşeden olur (K39) & Bütün insanlar ölüyor ya da yaralanıyor (K35) \\
& Enkaz & Can ve mal kaybına neden olur insanlar çadırda yaşar (K65) \\
& Fil & Her şeyi insanları yıkar geçer (K1) \\
\hline
\end{tabular}

Tablo 8'de görüldüğü üzere "Toplumsal Sonuçlar" alt kategorisi altında 8 metafor bulunmaktadır. Metaforlara ilişkin açıklamalar incelendiğinde katılımcıların depremi toplumsal etkiler açısından değerlendirdikleri görülmektedir. Katılımcıların "Depremin Sonuçları" kategorisinden "Dinsel Sonuçlar" alt kategorisine ait metaforlar ve açıklama örnekleri Tablo 9' da verilmiştir.

Tablo 9. Dinsel Sonuçlar Alt Kategorisine Ait Kodlar ve Açılama Örnekleri

\begin{tabular}{|c|c|c|}
\hline Alt Kategori & Metafor & Açıklama örnekleri \\
\hline \multirow{3}{*}{ 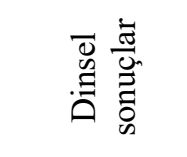 } & Kiyamet & Herkes kendinden sorumludur. Cezan varsa çekersin (K52) \\
\hline & Mahşer & $\begin{array}{l}\text { Aniden gelip insanların toplu olarak canını alır. Her yer mahşer } \\
\text { alanı olur (K128) }\end{array}$ \\
\hline & Ezan & Allah'a yaklaştırır (K73) \\
\hline
\end{tabular}

Tablo 9'de görüldüğü üzere "Dinsel Sonuçlar" alt kategorisi altında 3 metafor bulunmaktadır. Metaforlara ilişkin açıklamalar incelendiğinde katılımcıların depremi dini açıdan değerlendirdikleri görülmektedir. "Depremin Sebepleri" kategorisi altında yer alan metaforlar "dinsel sebepler" kategorisi altında toplanmıştır. Bu alt kategoriye ait metaforlar ve açıklama örnekleri Tablo 10'da verilmiştir.

Tablo 10. Dinsel Sebepler Alt Kategorisine Ait Kodlar ve Açılama Örnekleri

\begin{tabular}{cll}
\hline Alt Kategori & Metafor & Açıklama örnekleri \\
\hline & Kiyamet alameti & Görülmemiş bir şey. Adeta kıyamet gelmiş (K58) \\
& Felaket habercisi & Yapılan kötülükler ve deprem. Bir felaket haberi getiren şey (K67) \\
Kiyamet gününde herkes kaçar, korkar. Depremde de öyledir \\
Kiyamet provası & (K150) \\
& Ölüm zamanı & Başlangıcın sonudur (K70) \\
Ceza & Insanların hayatlarında yaptıkları hatalar sebeptir (K56) \\
Uyandırma & Kötülüklerin kimsenin yanına kalmaması gerek (K47) \\
cezası & Allah kötüleri cezasız bırakmaz (K100) \\
& Sinav &
\end{tabular}

Tablo 10'da görüldüğü üzere "Dinsel Sebepler" alt kategorisi altında 7 metafor bulunmaktadır. Metaforlara ilişkin açıklamalar incelendiğinde katılımcıların depremin olma sebebini dini açıdan değerlendirdikleri görülmektedir.

\section{TARTIŞMA, SONUÇ VE ÖNERILER}

Sivrice depremini yaşamış ortaokul öğrencilerinin "depreme" ilişkin metaforik algılarını belirlemek amacıyla yapılan bu çalışmada, elde edilen bulgular doğrultusunda aşağıda ifade edilen sonuçlara ulaşılmıştır.

Araştırma sonucunda katılımcıların 76 farklı metafor ürettikleri sonucuna ulaşılmıştır. Metaforlar, ortak özellikleri ve kullanım gerekçelerine göre üç kategori ve sekiz alt kategori 
altında toplanmıştır. Kategoriler; "Depremin Oluşma Şekli", "Depremin Sonuçları" ve "Depremin Sebepleri"; alt kategoriler ise makine/araç-gereç, doğal afet, insan davranışı ve zaman psikolojik sonuçlar, toplumsal sonuçlar ve dinsel sonuçlar, dinsel sebepler şeklinde isimlendirilmiştir. Katılımcılar tarafından en çok tekrarlanan metaforların; salıncak, kıyamet, ölüm, beşik, korku felaket ve kıyamet alameti metaforları olduğu sonucuna ulaşılmıştır. Depreme ilişkin metaforların, depremlerin insan ve doğa üzerindeki olumsuz ve yıkıcı etkileriyle ilişkilendirilerek ifade edilmesi önemli bir sonuç olarak görülmektedir. Araştırma sonucunda depremi yaşamış öğrencilerin depremlere ilişkin ürettikleri metafoların yıkıcı ve olumsuz etkileriyle değerlendirilmesi Demirkaya (2007a, 2007b,), Aksoy (2013), Karakuş (2013), Değirmenci (2018) ve Karakuş (2019) tarafından yapılan çalışmalarla benzerlik göstermektedir.

"Depremin Oluşma Şekli" kategorisinde katılımcılar tarafından 36 metafor, "Makine/araçgereç" alt kategorisinde öğrenciler tarafindan 18 metafor üretilmiştir. Araştırmaya katılan öğrenciler bu kategoride ortaya koydukları metaforlar ile (Salıncak, beşik, gemi, yatak, kanepe, sıra, gondol, traktör v.b) depremi daha çok bir makineye ya da bir araca benzetmişlerdir. Doğal Afet" alt kategorisinde öğrenciler tarafından 10 metafor üretilmiştir. Bu kategoride öğrenciler depremleri "su dalgası, deniz dalgası, çığ, sel, yer yarığı, meteorun yere düşmesi, rüzgâr, kayaların savaşı" gibi doğal afetlere benzetmişlerdir. Depremler ve doğal afetler arasında kurulan bu ilişkiyi deprem sonrasında oluşan korku ve endişenin dışa vurumu olarak değerlendirmek mümkündür. Aynı zamanda doğal afetler karşısında yaşanan çaresizlik hissinin yansıması olarak da değerlendirilebilir. "İnsan Davranışı" alt kategorisinde öğrenciler tarafindan 4 metafor üretilmiştir. Katılımcılar depremi "kızgınlık, arkadaşın itmesi, düşman ve bebek" gibi insana özgü hallere benzeterek açıklamışlardır. Bu kategoride ifade edilen düşünceler, depremlerin büyük bir korkuya ve endişeye neden olduğu şeklinde yorumlanabilir. Benzer şekilde "Zaman" alt kategorisi altında öğrenciler tarafindan 4 metafor üretilmiştir. Katılımcılar depremin oluşum şeklini "habersiz misafir, saman alevi, habersiz canavar ve can alıcı" gibi insan davranışlarına ve doğada oluşan durumlara benzeterek açıklamışlardır. Bu kategoride özellikle depremlerin aniden oluşmasına bağlı olarak ortaya çıkan duyguların yansıması görülmektedir. "Doğal Afet" alt kategorisinde öğrenciler tarafından üretilen metaforların geneline bakıldığında deprem sonrasında korku, endişe ve çaresizlik gibi duyguların yaşandığı görülmektedir. Deprem gibi aniden gelişen ve önlenmesi mümkün olmayan bir doğa olayının bu tür sonuçlarının olması kaçınılmazdır. Elde edilen bulgular Demirkaya (2007a, 2007b), Kaya (2010), Karakuş (2013), Aksoy (2013), Yazıc1 ve Kalın (2018), Karakuş (2019) tarafından yapılan araştırma bulgularıyla benzerlik göstermektedir.

Kaya (2010) tarafından yapılan çalışmada ortaokul öğrencileri “deprem” kavramına ilişkin 55 farklı ve kabul edilebilir metafor oluşturmuşlardır. Araştırma sonucunda, ortaokul öğrencilerinin \% 34'ünün depremi (30 metafor) "yakıcı ve yıkıcı olay" olarak algıladıkları sonucuna ulaşılmıştır. Aksoy (2013) tarafından yapılan çalışmada katılımcılar deprem kavramına ilişkin olarak 40 farklı metafor üretmişlerdir. Katılımcılar tarafindan oluşturulan metaforlardan hareketle; istenmeyen duygu/olay, yok edici güç, zarar veren doğal olay gibi kategoriler oluşturulmuştur. Oluşturulan metafor kategorilerinde genel olarak depremin istenilmeyen ve zarar veren bir güç olarak algılandığı sonucuna ulaşılmıştır. Değirmenci (2018) tarafından sınıf öğretmeni adaylarının "doğal afet” kavramına ilişkin geliştirdikleri metaforların incelendiği çalışmada, doğal afetlere ilişkin 56 metafor geliştirilmiştir. Bu metaforlardan 17 tanesi "Zarar verici ve yok edici olarak doğal afet" kategorisinde ifade edilmiştir. Doğal afetlerle ilişkilendirilen metaforların korku ve kaygı temalı olması bu çalışmada elde edilen bulgularla benzerlik göstermektedir. Yazıcı ve Kalın (2018) tarafından doğal afetler için kavramsal metaforların analiz edildiği çalışmada, doğal afetlerle ilişkilendirilen metaforlardan "insan, sınav, hayalet, kanser, çocuk, kıyamet ve ceza" metaforları öne çıkmaktadır. Karakuş (2019) tarafından yapılan çalışmada ise öğrenciler "deprem" anahtar kavramını "yıkım ve ölüm” gibi kelimelerle ilişkilendirmişlerdir. Bu metaforların deprem sonrasında yaşanan duygu ve düşüncelerin etkisiyle oluştuğu sonucuna varılabilir. 
"Depremin Sonuçları" kategorisinde katılımcılar tarafından 32 metafor üretilmiştir. "Psikolojik Sonuçlar" alt kategorisinde öğrenciler tarafından 21 metafor oluşturulmuştur. Katılımcılar tarafından ortaya konan "korku filmi, acılı anne, yıkılmış hayaller, çaresizlik, ruhsal bozukluk, sinir patlaması, karanlık, vahşi bir hayvan ve korku" gibi metaforlar, deprem sonrasında ortaya çıkan psikolojik gerilimi bir yansıması olarak değerlendirilebilir. Elde edilen bu bulgular Demirkaya (2007a, 2007b) ve Aksoy (2013) tarafından yapılan çalışmalarda elde edilen bulgularla benzerlik göstermektedir. "Toplumsal Sonuçlar" alt kategorisiyle ilgili olarak öğrenciler tarafından 8 metafor oluşturulmuştur. Katılımcılar tarafından yapılan açıklamalarda depremin yıkıcı etkisinden ve neden olduğu sorunlardan bahsedilmiştir. Bu kategoride yer alan "felaket, cansız varlık, darbe, ağaçtan sallanan elma, silah, savaş, enkaz ve fil" gibi metaforlarda, depremin neden olduğu can ve mal kaybının etkisi görülmektedir.

"Dinsel Sonuçlar "alt kategorisiyle ilişkili olarak öğrenciler tarafından 3 metafor ortaya konulmuştur. Metaforlara ilişkin açıklamalara bakıldığında katılımcıların depremi dini imgelerle ilişkilendirerek ifade ettikleri görülmektedir. "Kıyamet ve mahşer" metaforlarının dini düşüncedeki 'hayatın sonu' düşüncesiyle ilişkilendirilmiş olması, depremin ortaya çıkardığı korkuyu ve yaşanan çaresizliğin anlaşılması açısından önemlidir. Kaya'nın (2010) yaptığı çalışmada yer alan "Deprem bir yol olarak ölümü ifade eder" alt kategorisinde 'Ölüm meleği, kara melek, kıyamet günü, ölüm’ gibi metaforlar yer almaktadır. Aksoy (2013) tarından yapılan çalışmada yer alan "İstenmeyen Duygu, Olay" kategorisinde deprem "Kıyamet günü, kıyametin bir parçası ve ölüm" gibi metaforlarla ifade edilmiştir. "Karakuş (2013) tarafindan yapılan çalışmada yer alan "Hayal edilen dini inanış" kategorisinde deprem, depremi yaşamış öğrenciler tarafindan "Kıyamet günü, Ölüm, Azrail, Hızır Aleyhiselam, Nuh Tufanı" gibi metaforlarla ifade edilmiştir. Yazıcı ve Kalın (2018) tarafından yapılan çalışmada, doğal afetlerle ilgili olarak en çok üretilen metaforlardan birisi de "kıyamet" metaforu olmuştur. Değirmenci'nin (2019) sınıf öğretmeni adaylarının doğal afetlere ilişkin metafor algılarına belirlemek amacıyla yaptığ 1 çalışmada "Çaresizlik durumu olarak doğal afet" alt kategorisinde "Kıyamet, felaket, ölüm, çaresizlik, ecel, mahşer günü, yokluk' gibi metaforlar yer almaktadır. Ayrıca "Olağanüstü varlık olarak doğal afet" kategorisinde yer alan "Azrail ve şeytan" gibi metafolar ile depremlerin dini kavramlarla ilişkilendirildiği söylenebilir. Öztürk'ün (2013) sınıf öğretmeni adaylarının deprem deneyimleri üzerine yaptığı çalışmada elde edilen verilere bakıldığında ise deprem sonrasında dini değerlere olan bağlılığın arttığını gösteren sonuçlara ulaşılmıştır. Dolayısıyla araştırma sonucunda elde edilen veriler, alanda yapılan çalışmalarla benzerlik göstermektedir.

"Depremin Sebepleri" kategorisi altında yer alan metaforlar "Dinsel Sebepler" kategorisi altında toplanmıştır. "Dinsel Sebepler" alt kategorisiyle ilişkili olarak öğrenciler tarafından 7 metafor ortaya konulmuştur. Katılımcıların metaforlarla ilgili olarak yaptıkları açıklamalara bakıldığında, depremlerin oluşum nedenini dini sebeplere bağladıkları görülmektedir. "Kıyamet alameti, felaket habercisi, kıyamet provası, ölüm zamanı, caza, uyandırma cezası, sınav" gibi metaforların, dini duygu ve düşüncelerin etkisiyle ifade edilmiş olması, depremlere ilişkin toplumsal algının izlerini sürmek açısından önemi bir veri olarak değerlendirilebilir. Nitekim Demirkaya (2007a, 2007b) tarafından yapılan çalışmalarda depremlerin sebepleriyle ilgili olarak katılımcılar tarafından dini düşüncelere yer verilmiştir. Aksoy (2013) tarafından yapılan çalışmada "Doğru olanı işaret eden" kategorisinde yer alan "Bir gazap, Uyandırıcı alarm ve Uyarı" gibi metaforlar ile depremlerin sebepleri dini duygu ve düşüncelerle ilişkilendirilmiştir.

Yapılan bu çalışmayla depremi yaşamış öğrencilerin depreme ilişkin duygu ve düşüncelerini ifade edebildikleri metaforlar belirlenmiş ve öğrencilerin depreme ilişkin alg1 düzeyleri tespit edilmiştir. Elde edilen bu veriler afet eğitimi çalışmalarının öğrenci düzeyine uygun bir şekilde gerçekleştirilmesi için kullanılabilir. Ayrıca elde edilen bu veriler deprem bölgesinde bulunan öğrencilerin duygu ve düşüncelerinin kapsamlı bir şekilde değerlendirilebilmesine yardımcı olabilir. Afetlerle ilgi eğitimlerin öğrenci düzeyine göre hazırlanmasının, afet eğitimiyle ilgili çalışmaların kalıcı ve etkili bir şekilde gerçekleştirilmesine imkân sağlayacağı düşünülmektedir. 


\section{KAYNAKÇA}

AFAD, (2020). 24 Ocak 2020 Sivrice (Elazı̆̆) Mw 6.8 depremine ilişkin ön değerlendirme raporu. Retrieved from https://deprem.afad.gov.tr/downloadDocument?id=1825

AFAD. (2018). Türkiyede afet yönetimi ve doğal kaynaklı afet istatistikleri. Ankara: Afet ve Acil Durum Yönetimi Başkanlığı.

Aksoy, B. ve Sözen, E. (2014). Lise öğrencilerinin coğrafya dersindeki deprem eğtimine ilişkin görüşlerinin çeşitli değişkenler açısından incelenmesi (Düzce ili örneği). Uşak Üniversitesi Sosyal Bilimler Dergisi, 7(1), 279-297.

Aksoy, B. (2013). Depremi yaşamış olan 9. sınıf öğrencilerinin "deprem" kavramına yönelik algılarının nitel açıdan incelenmesi. Zeitschrift für die Welt der Türken, 5(1), 247-265.

Altay, S. (2008). İlköğretimde sosyal bilgiler dersinde depremle ilgili konuların irdelenmesi. Yayınlanmış Yüksek Lisans Tezi. Abant İzzet Baysal Üniversitesi Sosyal Bilimler Enstitüsü, Bolu.

Arslan, M. M. ve Bayrakçı, M. (2006). Metaforik düşünme ve öğrenme yaklaşımının eğitimöğretim açısından incelenmesi. Milli Ĕgitim, 35(171), 100-108.

Ateş, M. ve Karatepe, A. (2013). The analysis of University students' perceptions towards "environment" concept with the help of metaphors. The Journal of Academic Social Science Studies-(JASS), 6(2), 1327-1348.

Aydin, S. (2019). Determination of prospective science teachers' knowledge levels about earthquake. International Journal of Earth Sciences Knowledge and Applications, 1(1) 2831 .

Kırıkkaya, E., Ünver, A. ve Çakın, O . (2011). İköğretim fen ve teknoloji programında yer alan afet eğitimi konularına ilişkin öğretmen görüşleri. Necatibey Eğitim Fakültesi Elektronik Fen ve Matematik Ĕ̈itimi Dergisi, 5(1), 24-42.

Baytiyeh, H. ve Naja, M. (2013). Promoting earthquake disaster mitigation in Lebanon through civic engagement. Disaster Prevention and Management, 22(4), 340-350.

Büyükalan-Filiz, S. ve Türkmenli, A. (2019). Metaphorical perceptions of participants to nonformal training courses on drawing. Sosyal Bilimler Araştırmaları Dergisi, 9(2), 375-389.

Büyüköztürk, Ş., Çakmak, E., Akgün, Ö. E., Karadeniz, Ş. ve Demirel, F. (2016). Bilimsel araştırma yöntemleri [Scientific research methods] (22. bask1). Ankara: Pegem A Yayıncilik.

Cambridge Dictioanary. (2020, 06 05). Cambridge Dictioanary. Cambridge Dictioanary: https://dictionary.cambridge.org/tr/s\%C3\%B6zl\% $\%$ C3\%BCk/ingilizcet\%C3\%BCrk\%C3\%A7e/metaphor adresinden alınd.

Collins English Dictionary. (2020, 06 05). Collins English Dictionary. Collins: https://www.collinsdictionary.com/ adresinden alınd1.

Creswell, J. W. (2007). Research design: Qualitative, quantitative, and mixed methods approaches. California: Sage Publications Inc.

Cvetković, V.M., Slavoljub, D., Marina, P., Saša, M., Vladimir, J. ve Jasmina, G. (2015). Knowledge and perception of secondary school students in Belgrade about earthquakes as natural disasters. Polish Journal of Environmental Studies, 24(4), 1553-1561.

Çakar, Ö. (2008). İlköğretim 5. sınıf sosyal bilgiler dersininin deprem bilinci geliştirmedeki rolüne dair ögretmen görüşleri. Yayınlanmış Yüksek Lisans Tezi. Fırat Üniversitesi Sosyal Bilimler Enstitütüsü, Elazı̆̆. 
Çelik, İ., Dur, D. ve Bayar, E. M. (2016). Okul öncesi dönem çocuklarında deprem algısı (Ağrı ili örneği). TURAN-SAM Uluslararası Bilimsel Hakemli Dergisi, 8, 63-69.

Çelikkaya, T. ve Seyhan, O. (2017). Sosyal bilgiler öğretmenlerinin ve öğretmen adaylarının evrensel değerlere ilişkin metafor algıları. E-Uluslararası Ĕgitim Araştırmaları Dergisi, 8(3), 65-87.

Çoban, M., Sözbilir, M. ve Göktaş, Y. (2017). Deprem deneyimini yaşamış kişilerin deprem öncesi hazırlık algılarının belirlenmesi: bir durum çalışması. Doğu Coğrafya Dergisi, 37, 113-134.

De Haen, H. ve Hemrich, G. (2007). The economics of natural disasters: Implications and challenges for food security. Agricultural Economics, 37(1), 31-45.

Değirmenci, Y. (2019). Sınıf öğretmeni adaylarının "doğal afet” kavramına ilişkin geliştirdikleri metaforların incelenmesi. International Journal of Geography and Geography Education (IGGE), s. 83-94.

Değirmençağ, Ş. A. ve Cin, M. (2016). Türkiye'deki deprem eğitimi araştırmaları: betimsel içerik analizi. YYÜ Ĕ̈itim Fakültesi Dergisi, 1, 301-313.

Demirkaya, H. (2007a). İlköğretim 5. 6. ve 7. sınıf öğrencilerinin depreme yönelik tutumlarının çeşitli değişkenlere göre incelenmesi. Türkiye Sosyal Araştırmalar Dergisi, 11(3), 37-49.

Demirkaya, H. (2007b). İlköğretim öğrencilerinin deprem kavramı algılamaları ve depreme ilişkin görüşleri. Mehmet Akif Ersoy Üniversitesi Eğitim Fakültesi Dergisi, 8, 68-76.

Doğan, E. ve Koç, H. (2017). Sosyal bilgiler dersinde deprem konusunun dijital oyunla öğretiminin akademik başarıya etkisi. Uluslararası Türk Eğitim Bilimleri Derigisi , 5(8), 90-100.

Doğan, Y. (2017). Ortaokul öğrencilerinin çevre kavramına ilişkin sezgisel algıları: bir metafor analizi. Ahi Evran Üniversitesi Kırşshir Eğitim Fakültesi Dergisi (KEFAD), 18(1), 721740 .

Ekici, G. (2016). Biyoloji öğretmeni adaylarının mikroskop kavramına ilişkin algılarının belirlenmesi: bir metafor analizi çalışması. Journal of Kirsehir Education Faculty, 17(1), 615-636.

Ergünay, O. (1996). Afet yönetimi: genel ilkeler, tanımlar, kavramlar. Ankara: TÜBİTAK Deprem Sempozyumu Bildiriler Kitabi.

Gökoğlu, S. (2017). Programlama eğitiminde algoritma algısı: Bir metafor analizi. Cumhuriyet International Journal of Education, 6(1), 1-14.

Hobsbawm, E. J. (2013). Sermaye Çăğ (5. Baskı). Dost Yayınevi, İstanbul.

Hogler, R., Gross Michael A., Hartman Jackie L. ve Cunliffe Ann L. (2008). Meaning in organizational communication: why metaphor is the cake, not the icing. Management Communication Quarterly. 21, 393-412.

Izadkhah, Y. O. ve Gibbs, L. (2015). A study of preschoolers' perceptions of earthquakes through drawing. International Journal of Disaster Risk Reduction, 14, 132-139.

İmamoğlu, M. Ş. ve Çetin, E. (2007). Güneydoğu anadolu bölgesi ve yakın yöresinin depremselliği. D.Ü.Ziya Gökalp Ĕgitim Fakültesi Dergisi, S. (9), 93-103.

İzbırak, R. (1991). Yerblimi Bilgileri. İstanbul: M.E.B. Yayınları.

Johnson, V. A. ve Ronan, K.R. (2014). Classroom responses of New Zealand school teachers following the 2011 Christchurch earthquake. Natural Hazards, 72, 1075-1092. 
Kadığlu, M. (2005). Afete hazırlık ve afet bilinci eğitiminde verilen mesaların satandartizasyonu. Demrem Sempozyumu Kocaeli 2005, 1500-1502.

Karakuş, U. (2013). Depremi yaşamış ve yaşamamış öğrencilerin deprem algılarının, metafor analizi ile incelenmesi. Doğu Coğrafya Dergisi, 18(29), 97-116.

Karakuş, U. (2019). Sosyal bilgiler öğretmen adaylarının doğal afet kavramlarına ilişkin algılarının kelime ilişkilendirme testi aracılığıyla incelenmesi. Cumhuriyet Uluslararası Ĕ̈itim Dergisi, 8(3), 735-751.

Kasapoğlu, K. E. (2007). Depremler ve Türkiye hakkında bilmek istedikleriniz. İstanbul: Berkay Ofset.

Kaya, H. (2010). Metaphors developed by secondary school students towards "earthquake" concept. Educational Research and Review, 5(11), 712-718.

Kıvrak, Ö. (2019). Karabük ilinde deprem farkındalığı. Yüksek Lisans Tezi. Karabük Üniversitesi Fen Bilimleri Enstitüsü, Karabük.

Kung, Y. W. ve Chen, S. H. (2012). Perception of earthquake risk in Taiwan: Effects of gender and past earthquake experience. Risk Analysis: An International Journal, 32(9), 15351546.

Lincoln, Y. S. ve Guba, E. G. (2013). The constructivist credo. California, CA: Left Coast Press.

MEB. (2018a). Sosyal Bilgiler Dersi Öğretim Programı. Ankara: Milli Eğitim Bakanlığı.

MEB. (2018b). Fen Bilimleri Öğretim Programı. Ankara: Milli Eğitim Bakanlığı.

Miles, M. B. ve Huberman, A. M. (1994). Qualitative data analysis (2. Bask1).Newbury Park, CA: Sage.

Mutch, C. (2015). The role of schools in disaster settings: Learning from the 2010-2011 New Zealand earthquakes. International Journal of Educational Development, 41, 283-291.

Navakanesh, B., Shah, A. A. ve Prasanna, M. V. (2019). Earthquake education through the use of documentary movies. Frontiers in Earth Science, 7(42), 1-16.

Obara, K. ve Kato, A. (2016). Connecting slow earthquakes to huge earthquakes. Science, 353(6296), 253-257.

Öcal, A. (2005). İlköğretim sosyal bilgiler dersinde deprem eğitiminin değerlendirilmesi. Gazi Eğitim Fakültesi Dergisi, 25(1), 169-184.

Öcal, A. (2007). İlköğretim aday öğretmenlerinin deprem bilgi düzeyleri üzerine bir araştırma. Mehmet Akif Ersoy Üniversitesi Eğitim Fakültesi Dergisi, 8, 104-110.

Özdemir, S. ve Akkaya, E. (2013). Genel lise öğrenci ve öğretmenlerinin okul ve ideal okul algilarının metafor yoluyla analizi. Kuram ve Uygulamada Eğitim Yönetimi, 19(2), 295322.

Özel, G. ve Solmaz, A. (2012). Tüurkiye'de deprem tekrarlanma zamanının tahmini ve neoteknik bölgelere göre depremselliğin markov zinciri ile incelenmesi. Çankaya University Journal of Science and Engineering, (9), 125-138.

Özkul, B. ve Karaman, A. E. (2007). Doğal afetler için risk yönetimi. TMMOB Afet Sempozyumu Bildiriler Kitabı, 251-260.

Öztürk, M. K. (2013). Sınıf öğretmeni adaylarının deprem deneyimleri üzerine bir araştırma. Hacettepe Üniversitesi Eğitim Fakültesi Dergisi, 28(1), 308-319.

Pampal, S. (1999). Depremler. İstanbul: Alfa Yayınları. 
Patton, M. Q. (2002). Qualitative research \& evaluation methods (3rd ed.). London: Sage Publications, Inc.

Potts, A. ve Semino, E. (2019). Cancer as a Metaphor, Metaphor and Symbol, 34(2), 81-95,

Rahman, M. L. (2019). High school students' seismic risk perception and preparedness in Savar, Dhaka. Educational Research and Reviews, 14(5), 168-177.

Rij, E.V. (2016). An approach to the disaster profile of People's Republic of China 1980-2013. Emergency and Disaster Reports, 3(4), 1-48.

Saban, A, Koçbeker, B. N. ve Saban, A. (2006). Öğretmen adaylarının öğretmen kavramına ilişkin algilarının metafor analizi yoluyla incelenmesi. Kuram ve Uygulamada Ĕgitim Bilimleri Dergisi, 6(2), 461-522.

Shaw, D. M. ve Mahlios, M. (2011). Literacy metaphors of pre-service teachers: Do they change after instruction? Which metaphors are stable? How do they connect to theories? Journal of Education for Teaching: International Research and Pedagogy, 37, 77-92.

Shenton, A. K. (2004). Strategies for ensuring trustworthiness in qualitative research projects. Education for Information, 22, 63-75.

Sözen, E. (2019). The earthquake awareness levels of undergraduate students. Journal of Pedagogical Research, 3(2), 87-101.

Şahan, K. (2017). Metafor ne değildir? The Journal of Academy, 8, 166-176.

Şahin, C. ve Sipahioğlu Ş. (2002). Doğal afetler ve Türkiye. Ankara: Gündüz Eğitim ve Yayıncilik.

Tanhan, F. ve Mukba, G. (2015). Depreme ilişkin algının deprem yaşayan ilköğretim öğrencilerinin görüşlerine dayalı olarak incelenmesi. International Journal of Human Sciences, 12(2), 1581-1601.

TDK. (2020). Yabanıcı Sözlere Karşıllılar Kılavuzu. Türk Dil Kurumu: https://sozluk.gov.tr/ adresinden alındi.

Thibodeau, P. H., Flusberg, S. J. ve Holmes, K. (2017). Solving the Puzzle to Reach the Summit: Using Metaphor to Gauge Public Perceptions of Science. In CogSci, 3320-3325.

TMMOB. (2011). Türkiye’de Deprem Gerçeği ve TMMOB Makina Mühendisleri Odasının Önerileri Oda Raporu. Ankara: TMMOB Makina Mühendisleri Odası.

Tok, E. (2018). Okul öncesi öğretmen adaylarının oyuna ilişkin algıları: Metafor analizi örneği. Kastamonu Ĕgitim Dergisi, 26(2), 599-611.

Tsai, C. (2001). Ideas about earthquakes after experiencing a natural disaster in Taiwan: An analysis of students' worldviews. International Journal of Science Education, 23(109), 1007-1016.

Yazıcı, Ö. ve Kalın Ulu, Ö. (2018). "Doğal afet” için kavramsal metaforların karşılaştırmalı analizi. Kafkas Eğitim Araştırmaları Dergisi, 5(1), 25-40.

Yi, L., Shao-Hong, W. U., Zhong-Chun, X. U. ve Erfu, D. A. I. (2011). Methodology for assessment and classification of natural disaster risk: A case study on seismic disaster in Shanxi Province. Geographical Research, 30(2), 195-208.

Yükseller, M. (2019). Çanakkale onsekiz mart üniversitesi sağll yüksekokulu 1. sınıf ögrencilerinin deprem bilinci bilgi düzeyleri. Yüksek Lisans Tezi. Çanakkale Onsekiz Mart Üniversitesi Eğitim Bilimleri Enstitüsü, Çanakkale.

Zhou, L., Wu, X., Xu, Z. ve Fujita, H. (2018) Emergency decision making for natural disasters: an overview. International Journal of Disaster Risk Reduction, 27, 567-576. 


\section{EXTENDED ABSTRACT}

Within the scope of disaster education studies, earthquakes are considered as the subject of many studies. It is possible to explain this situation by the impact of earthquakes in Turkey. Especially after the 1992 Erzincan earthquake and 1999 Gölcük earthquakes, research on earthquakes has increased.(Aksoy \& Sözen, 2014; Altay, 2008; Çakar, 2008; Çelik, Dur \& Bayar, 2016; Çoban, Sözbilir \& Göktaş, 2017; Değirmençağ \& Cin, 2016; Doğan \& Koç, 2017; Karakuş, 2013; Öcal, 2007; Öztürk, 2013; Sözen, 2019; Yükseller, 2019). A similar situation is also noticeable in studies conducted outside Turkey (Izadkhah \& Gibbs, 2015; Johnson \& Ronan, 2014; Navakanesh, Shah \& Prasanna, 2019; Mutch, 2015; Tsai, 2001). Because earthquakes are natural disasters that deeply affect human life, they deeply affect human consciousness both during the time period in which they occur and later (Karakuş, 2013). For this reason, it is important to examine the level of knowledge, perceptions and opinions of the students who have experienced the earthquake (Aydın, 2019; Cvetković et al., 2015; Kung \& Chen, 2012; Rahman, 2019).

Variables such as culture, age, class level can affect the perception of young children about earthquakes (Rahman, 2019). Therefore, it is important to examine the perceptions of secondary school students about earthquakes. Due to the lack of a sufficient number of studies examining earthquake perceptions of secondary school students who have experienced earthquakes in Turkey, it is believed that the current study will contribute to the field.Different techniques, ways and measurement tools are used to determine students ' perceptions of a phenomenon, concept or event. In the current study, students ' perceptions of earthquakes were examined through metaphor. As a matter of fact, one of the best ways to reflect individuals ' thoughts about a particular concept and reveal their perceptions is the metaphors they have (Potts \& Semino, 2019; Özdemir \& Akkaya, 2013).

Earthquake education studies, which are one of the most important subheadings of disaster education studies, can improve the efficiency of these educational activities in accordance with the detection levels of students. In this context, it is expected that the data to be obtained will be arranged in accordance with the perception methods of the students in the earthquake education studies carried out in schools and thus the educational activities will be made more efficient. In this direction, answers to the sub-problems given below were sought.

1. What are the metaphors that secondary school students who experienced an earthquake produce about an earthquake?

2. Which conceptual categories can metaphors of secondary school students who have experienced an earthquake concerning the concept of "earthquake" be expressed under in terms of common characteristics?

The phenomenology design, one of the qualitative research methods, was used in the study. The study group of the research consisted of 151 secondary school students. The participants of the study were selected from the purposeful sampling method according to the maximum diversity sampling method. In the study, the metaphors of secondary school students about earthquake were collected using an open-ended questionnaire consisting of two parts.

As a result of the research, it was concluded that participants produced 76 different metaphors. Metaphors are grouped under three categories and eight subcategories based on their common characteristics and reasons for use. The categories are named" How an earthquake occurs"," the consequences of an earthquake" and "the causes of an earthquake". Subcategories are named as machines/tools-equipment, natural disaster, human behavior, time, psychological consequences, social consequences, religious consequences and religious causes. It was concluded that the metaphors most frequently repeated by the participants were the metaphors of swing, doomsday, death, cradle, fear, disaster and doomsday. It is seen as an important result that metaphors related to earthquakes are expressed in relation to the negative and destructive effects 
of earthquakes on humans and nature. As a result of the research, the evaluation of the metaphors produced by students who experienced earthquakes with their destructive and negative effects is similar to the studies conducted by Demirkaya (2007b), Aksoy (2013), Karakuş (2013), Değirmenci (2018) and Karakuş (2019).

In this study, metaphors were determined in which students who experienced the earthquake could express their feelings and thoughts about the earthquake, and the level of perception of students about the earthquake was determined within a general framework. These data can be used to carry out disaster education studies in accordance with the student level. In addition, these data can help to comprehensively assess the feelings and thoughts of students in the earthquake zone. It is believed that planning disaster education activities in accordance with the student level will allow the educational work to be carried out permanently and effectively. 